\title{
Developmental Ability of Miniature Pig Embryos Cloned with Mesenchymal Stem Cells
}

\author{
Sung-Lim LEE ${ }^{1,2)}$, Eun-Ju KANG ${ }^{1)}$, Geun-Ho MAENG ${ }^{1)}$, Min-Jung KIM(1), Jun-Kyu PARK ${ }^{3)}$, \\ Tae-Suk KIM ${ }^{3)}$, Sang-Hwan HYUN ${ }^{4)}$, Eun-Song LEE ${ }^{5)}$ and Gyu-Jin $\mathrm{RHO}^{1,2)}$ \\ ${ }^{1)}$ College of Veterinary Medicine, Gyeongsang National University, Jinju 660-701, ${ }^{2)}$ Research Institute of Life Sciences, \\ Gyeongsang National University, Jinju 660-701, ${ }^{3)}$ Gyeongnam Livestock Promotion Research Institute, Sancheong 666- \\ 962, ${ }^{4)}$ College of Veterinary Medicine, Chungbuk National University, Cheongju 361-763 and ${ }^{5)}$ College of Veterinary \\ Medicine, Kangwon National University, Chuncheon 201-100, Korea
}

\begin{abstract}
The present study compared the developmental ability of miniature pig embryos cloned with fetal fibroblasts (FFs), bone marrow-derived mesenchymal stem cells (MSCs) and differentiated (osteocytes, adipocytes and chondrocytes) MSCs. MSCs were isolated from an approximately 1-month-old female miniature pig (T-type, PWG Micro-pig ${ }^{\circledR}$, PWG Genetics Korea). MSCs were differentiated into osteocytes, adipocytes and chondrocytes under controlled conditions and characterized by cell surface antigen profile using specific markers. These differentiated or undifferentiated MSCs, as well as FFs of miniature pig, were transferred into enucleated oocytes of domestic pigs. Data from 10 replicates involving 1567 cloned embryos were assessed in terms of developmental rates. The in vitro development rate to the blastocyst stage of embryos cloned with undifferentiated MSCs was significantly (P<0.05) higher than that of embryos cloned with differentiated MSCs and FFs. Surgical transfer of 523 two-cell stage embryos cloned with undifferentiated MSCs into five synchronized domestic pig recipients resulted in 5 cloned miniature pig offspring (1 stillborn and 4 viable) from 2 pregnant recipients. The results imply that MSCs might be multipotent and that they can be used to produce viable cloned miniature pigs that cannot be easily reproduced with differentiated somatic cells.
\end{abstract}

Key words: Animal cloning, Differentiation, Mesenchymal stem cells, Miniature pig, Nuclear transfer

(J. Reprod. Dev. 56: 256-262, 2010)

$\mathbf{T}$ he production of cloned animals by nuclear transfer (NT) has been increasingly studied as a potential approach to tissue and organ xenotransplantation with reduced immunogenicity for endstage organ failure. Several studies have suggested that miniature pigs, rather than nonhuman-primate species, are suitable as a donor animal for human xenotransplantation $[1,2]$ because miniature pigs are superior in terms of similarities in gross anatomy and physiology to humans as well as in terms of ethical issues. The NT efficiency, however, remains relatively low due to abnormalities throughout pre- and post-implantation development regardless of the species or type of donor cell [3]. A number of factors affect NT efficiency, including the NT technical process, activation protocol, recipient oocyte age, cell cycle stage and type of donor cells, which has been implicated in the precise reprogramming of chromatin and genomic imprinting. Among these factors, incomplete selection of donor cells has also been considered a prime cause for NT inefficiency.

Transfer of embryonic stem (ES) cells to produce cloned embryos has resulted in consistently higher numbers of viable offspring compared with somatic cells in mice [4, 5]. Moreover, embryos cloned with porcine mesenchymal stem cells (MSCs) and their derivatives along the osteogenic lineage give rise to an

Received: November 4, 2009

Accepted: December 7, 2009

Published online in J-STAGE: January 27, 2010

(C) 2010 by the Society for Reproduction and Development

Correspondence: G-J Rho (e-mail: jinrho@gnu.ac.kr) increase in the rate of preimplantation development compared with adult fibroblasts [6]. Our previous study on gene expression profiles demonstrated that some genes in embryos cloned with MSCs closely resembled those of in vivo counterparts [7]. These findings indicate that undifferentiated or less differentiated genomes might be more efficiently reprogrammed to re-activate the expression of early embryonic genes to enhance NT efficiency [8].

The present study, therefore, was conducted to compare the in vitro developmental ability of embryos cloned with undifferentiated and differentiated (osteocytes, adipocytes and chondrocytes) MSCs and fetal fibroblasts (FFs). Furthermore, the in vivo development of embryos cloned with undifferentiated MSCs was observed after transfer into surrogate animals.

\section{Materials and Methods}

\section{Media and chemicals}

All media were purchased from Gibco (Invitrogen Corporation, Grand Island, NY, USA) and all chemicals were purchased from Sigma-Aldrich Chemical (St. Louis, MO, USA), unless otherwise specified. The cell culture medium was advanced Dulbecco's Modified Eagle's Medium (ADMEM) supplemented with 10\% fetal bovine serum (FBS) and $1.0 \%$ penicillin-streptomycin (10,000 IU and 10,000 $\mu \mathrm{g} / \mathrm{ml}$, respectively, Pen-Strep; Gibco). TCM199 containing 5\% FBS, $0.57 \mathrm{mM}$ cysteine, $10 \mathrm{ng} / \mathrm{ml}$ epidermal growth factor (EGF), 25 mM HEPES, 2.5 mM Na-pyruvate, 1 $\mathrm{mM}$ L-glutamine, $1.0 \%$ Pen-Strep with or without $0.5 \mu \mathrm{g} / \mathrm{ml} \mathrm{LH}$ 
and $0.5 \mu \mathrm{g} / \mathrm{ml} \mathrm{FSH} \mathrm{(IVM+H} \mathrm{and} \mathrm{IVM-H,} \mathrm{respectively)} \mathrm{was} \mathrm{used} \mathrm{as}$ the medium for in vitro maturation (IVM) of the cumulus-oocyte complexes (COCs). The embryo culture medium was porcine zygote medium-3 (PZM-3) containing $3 \mathrm{mg} / \mathrm{ml}$ bovine serum albumin (BSA, Fraction V), essential amino acids and non-essential amino acids [9]. Tyrode's albumin lactate pyruvate medium containing $2 \mathrm{mg} / \mathrm{ml}$ BSA, $12 \mathrm{mM}$ sorbitol, $7.5 \mu \mathrm{g} / \mathrm{ml}$ cytochalasin B and $10 \mathrm{mM}$ HEPES (HEPES-TALP) was used for manipulation. The $\mathrm{pH}$ of all media was adjusted to 7.2-7.4, and the osmolarity was adjusted to $285 \mathrm{mOsM}$.

\section{Cell isolation and culture}

MSCs and FFs were isolated from female miniature pigs (Ttype, PWG Micro-pig ${ }^{\circledR}$, PWG Genetics Korea). Gelatinous bone marrow was extracted from the femur of an approximately 1month-old female to isolate the MSCs. The extracted bone marrow was mixed 1:1 (v/v) in phosphate-buffered saline (PBS), layered upon a Ficoll (density 1.077 g/ml, Amersham Biosciences, Uppsala, Sweden) gradient and centrifuged at $400 \times g$ for $40 \mathrm{~min}$ at 20 C. The buffy layer cells on the interface were cultured at $38.5 \mathrm{C}$ in a humidified atmosphere of $5 \% \mathrm{CO}_{2}$ in air. Non-adherent cells were gently removed 2 days after plating. Once confluent, the cells were dissociated with $0.25 \%$ (w/v) trypsin-EDTA solution and centrifuged at $500 \times g$ for $5 \mathrm{~min}$. The cells were passaged at a density of $1 \times 10^{4}$ cells $/ \mathrm{cm}^{2}$. FFs were isolated from a female fetus on approximately day 30 of gestation and obtained via hysterectomy from a pregnant miniature gilt. To isolate the fetal cells, the head, limbs and visceral organs of the fetus were removed, and the remaining tissues were washed in Dulbecco's phosphate-buffered saline (D-PBS) supplemented with 10\% FBS and treated with $0.05 \%(\mathrm{w} / \mathrm{v})$ trypsin-EDTA solution for $5 \mathrm{~min}$. After washing with ADMEM by centrifugation at $300 \times g$ for $10 \mathrm{~min}$, the cells were cultured at a final concentration of $2 \times 10^{5}$ cells $/ \mathrm{ml}$ at $38.5 \mathrm{C}$ in a humidified atmosphere of $5 \% \mathrm{CO}_{2}$ in air.

\section{In vitro differentiation and cytochemical staining}

Multilineage differentiation of MSCs and confirmation of their lineages were performed according to the methods previously explained [7, 10]. Briefly, cells were cultured in ADMEM until they reached $70-80 \%$ confluence in a $35-\mathrm{mm}$ dish under conductive conditions for osteogenic, adipogenic and chondrogenic differentiation for 3 weeks. The osteogenic medium consisted of ADMEM, 10\% FBS, $0.1 \mu \mathrm{M}$ dexamethasone, $50 \mu \mathrm{M}$ ascorbate-2phosphate and $10 \mathrm{mM} \beta$-glycerol phosphate.

The adipogenic medium consisted of ADMEM, $10 \%$ FBS, $1 \mu \mathrm{M}$ dexamethasone, $10 \mu \mathrm{M}$ insulin, $200 \mu \mathrm{M}$ indomethacin and $500 \mu \mathrm{M}$ 3-isobutyl-1-methylxanthine (IBMX). The chondrogenic medium mainly consisted of TGF- $\beta$. The cells were then stained with Alizarin-red S solution and von Kossa for identification of the mineralized matrix, oil red $\mathrm{O}$ staining for accumulation of the lipid droplets and Alcian blue 8 GX solution staining for synthesis of glycosaminoglycans. The alkaline phosphatase (AP) activity of the cells was detected using BCIP/NBT (Promega, Madison, WI, USA).

\section{Cell-surface antigen profile}

Specific markers, CD13 (aminopeptidase N), CD29 ( $\beta 1$-integrin), CD44 (hyaluronate receptor), CD45 (leukocyte common antigen), CD105 (endoglin) and CD133 (prominin) antibodies (Santa Cruz Biotechnology, CA, USA), were used to characterize the cell-surface antigen profile of the MSCs. Cells were fixed using 3.7\% formaldehyde in PBS for $30 \mathrm{~min}$ and incubated in PBS solution containing $0.3 \%$ Triton X-100 and $4 \mathrm{mg} / \mathrm{ml}$ BSA for 30 min. Samples were incubated with $5 \mu \mathrm{g} / \mathrm{ml}$ of primary CD antibodies and labeled with fluorescein isothiocyanate-conjugated secondary antibodies (1:100, Santa Cruz Biotechnology) for 30 min. Genomic DNA was labeled with $10 \mu \mathrm{g} / \mathrm{ml}$ propidium iodide solution in PBS for $15 \mathrm{~min}$, and stained samples were observed using a fluorescence microscope at $\times 400$ magnification (Nikon, Tokyo, Japan).

\section{Nuclear transfer (NT)}

The NT procedure was performed according to the previously described protocol [11] with minor modifications. Briefly, ovaries of domestic pigs were obtained from prepubertal gilts at a local slaughterhouse. COCs were aspirated from follicles 3-6 mm diameter with 19-G needle and 10-ml syringe. Sets of 100 COCs with uniform cytoplasm and multilayered cumulus cells were matured in $500 \mathrm{ml} \mathrm{IVM}+\mathrm{H}$ medium for $22 \mathrm{~h}$ and further cultured for an additional $20 \mathrm{~h}$ in IVM-H medium at $38.5 \mathrm{C}$ in a humidified atmosphere of $5 \% \mathrm{CO}_{2}$ in air. After removal of the cumulus cells, metaphase-II stage oocytes were selected for NT procedure. Oocytes which were enucleated their nuclei and the first polar bodies in manipulation medium were coupled with qualified nuclear donor cells (undifferentiated and differentiated MSCs and FFs). The couplets were oriented in a BTX Electro chamber (BTX, San Diego, CA, USA) filled with $0.28 \mathrm{M}$ mannitol solution containing $0.1 \mathrm{mM}$ $\mathrm{MgSO}_{4}, 0.05 \mathrm{mM} \mathrm{CaCl}_{2}$ and $0.1 \mathrm{mg} / \mathrm{ml} \mathrm{BSA}$ and pulsed with 2.0 $\mathrm{KV} / \mathrm{cm}$ direct current twice for $30 \mu$ sec using a BTX Electro Square Porator (ECM 830, BTX).

\section{Embryo evaluation}

Sets of 30 donor-cell-fused oocytes were cultured in $30 \mu$ drops of PZM-3 and maintained for 7 days at $38.5 \mathrm{C}$ in a humidified atmosphere of $5 \% \mathrm{CO}_{2}$ in air. The rates of cleavage and blastocyst development in vitro were assessed on day 2 and day 7, respectively. To compare total cell numbers, day 7 blastocysts were labeled with $5 \mu \mathrm{g} / \mathrm{ml}$ bisbenzimide and mounted onto a microscope slide, and their nuclei were counted under an inverted microscope equipped with epifluorescence.

\section{Estrus synchronization and embryo transfer}

The animal experiment was approved by the Animal Center for Medical Experimentation at Gyeongsang National University. To prepare the surrogate mother pigs, approximately 1-year-old female pigs (crossbreed of Landrace $\times$ Yorkshire) that were sexually mature and that had aborted by administration of $3 \mathrm{ml}$ of a synthetic analogue of prostaglandin $\mathrm{F}_{2} \alpha$ (Cyclix P, $92 \mu \mathrm{g} / \mathrm{ml}$ cloprostenol, Intervet, Netherlands) i. m. at day 30 of pregnancy were administered 1,000 IU eCG (Folligon, Intervet) and 2,500 IU hCG (Chorulon, Intervet) $72 \mathrm{~h}$ later to synchronize their estrus cycles. 
General anesthesia of the animals was performed through an intravenous injection of $4 \mathrm{mg} / \mathrm{kg}$ of azaperone (Stresnil ${ }^{\circledR}$, Janssen-Cilag, Belgium) and 1-2 mg/kg of tiletamine-zolazepam (Zoletil ${ }^{\circledR}$, Virbac, France). Approximately 100 miniature pig NT embryos at the 2-cell stage were surgically transferred into the oviducts of each surrogate domestic pig with synchronous estrus. Pregnancy of the surrogate mothers was initially monitored using an ultrasound (MyLab $^{\mathrm{TM}}$ 30, ESAOTE Pie medical, Netherlands) equipped with a 7.0-MHz convex transducer at approximately 28 days after transfer. Thereafter, pregnancy was monitored every 4 weeks until term.

\section{Microsatellite DNA analysis}

To clarify the offspring's genetic identity, polymorphic microsatellites from cloned piglets, surrogate mothers and MSCs that had been used as the nuclear donors were analyzed. Genomic DNA was extracted from the samples according to the manufactural instructions (GENE ALL ${ }^{\mathrm{TM}}$, General Biosystem, Korea). Eight highly polymorphic microsatellites (SW240, SW787, SW911, S0090, S0155, S0228, S0355, S0386) were selected for analysis. Polymerase chain reaction (PCR) amplification was performed using AmpliTaq Gold polymerase (Applied Biosystems, Foster City, CA, USA), $0.2 \mathrm{mM}$ of each dNTP, $0.5 \mathrm{mM}$ of each primer pair and 20 ng genomic DNA. PCR was performed with 40 cycles consisting of $94 \mathrm{C}$ for $30 \mathrm{sec}, 55 \mathrm{C}$ for $30 \mathrm{sec}$ and $72 \mathrm{C}$ for $30 \mathrm{sec}$ and analyzed using an ABI 1310 Genetic Analyzer and the GeneScan software (Applied Biosystems).

\section{Statistical analysis}

One-way analysis of variance (ANOVA; via SPSS) was used to analyze differences among the treatments. Duncan's and Tukey's multiple comparisons tests were used to compare the mean values of the treatments. Data are expressed as means \pm standard error of the mean (SEM), and differences were considered significant when $\mathrm{P}<0.05$.

\section{Results}

\section{Characterization and differentiation of MSCs derived from bone marrow}

The isolated MSCs appeared as stretched, single or spindleshaped cells and formed colonies during the primary culture period (Fig. 1a and b). After the cells were subcultured 3 or 4 times, homogeneous adherent MSCs were observed in the culture dishes. The cell-surface antigen profile of the MSCs was characterized by immunofluorescence assay with specific markers, CD13, CD29, CD44, CD45, CD105 and CD133 antibodies. These MSCs were observed to be positive for CD13 (aminopeptidase N), integrin CD29 ( $\beta 1$-integrin), matrix receptor CD44 (hyaluronate receptor) and CD105 (endoglin; Fig. 2a-d), but hematopoietic markers such as CD45 and CD133 (data not shown) were not observed.

To differentiate MSCs into distinct mesenchymal lineages such as osteogenic, adipogenic and chondrogenic, MSCs were cultured under conductive conditions for 3 weeks (Fig. 2e-h). Following exposure to osteogenic medium, MSCs were differentiated to osteocytes by forming a mineralized matrix and expressed AP activity (Fig. 1c). Identification of the mineralized matrix was confirmed by staining with Alizarin-red S and von Kossa (Fig. 2e and f). Culture of MSCs in adipogenic differentiation medium led to the marked appearance and formation of lipid vacuoles that filled the whole cytoplasm, which were visualized by oil red $\mathrm{O}$ staining (Fig. 2g). The chondrogenic potential of MSCs was characterized by staining with Alcian blue $8 \mathrm{GX}$, which indicated accumulation of sulfated proteoglycans (Fig. 2h).

In vitro developmental potential of embryos cloned with fetal fibroblasts (FFs) and undifferentiated and differentiated (osteocytes, adipocytes and chondrocytes) MSCs

Table 1 shows the development rates and total cell numbers of embryos cloned with FFs, bone marrow-derived MSCs and differentiated (osteocytes, adipocytes and chondrocytes) MSCs. The cleavage rate was significantly $(\mathrm{P}<0.05)$ higher in the embryos cloned with undifferentiated MSCs than in those cloned with FFs and differentiated MSCs (85\% vs. 64-75\%). Similarly, the blastocyst rate of those FFs and differentiated with undifferentiated MSCs $(47.7 \pm 3.2 \%)$ was significantly $(\mathrm{P}<0.05)$ higher than in the embryos cloned with other MSCs. The blastocyst rate of the embryos cloned with FFs was significantly $(\mathrm{P}<0.05)$ lower than those cloned with differentiated osteocytes, adipocytes and chondrocytes $(14.5 \pm 4.3$ vs. $34.5 \pm 3.3$, $31.1 \pm 4.1$ and $36.8 \pm 3.5 \%$, respectively). There were no significant $(\mathrm{P}<0.05)$ differences in the total cell numbers of embryos cloned with undifferentiated MSCs and differentiated osteocytes, adipocytes and chondrocytes (47.8 \pm 4.6 vs. $40.5 \pm 5.7,40.3 \pm 4.8$ and $42.2 \pm 6.2$, respectively), but the total cell numbers of those embryos were significantly $(\mathrm{P}<0.05)$ higher than that of the embryos cloned with FFs $(31.1 \pm 3.8)$.

\section{In vivo developmental potential of embryos cloned with undifferentiated MSCs}

Transfer of 523 two-cell stage embryos cloned with undifferentiated MSCs into five domestic pig surrogates yielded four pregnancies at around 28 days after transfer. Two of the pigs had a miscarriage in the second month of pregnancy for unknown reasons. The two remaining pigs delivered 5 offspring (body weights: 190, 300, 320, 320 and 320 g) at 115 days of gestation; four were viable, and one was stillborn (Table 2). To clarify the offspring's genetic identity, eight polymorphic microsatellites (SW240, SW787, SW911, S0090, S0155, S0228, S0355, S0386) were analyzed from the cloned piglets, surrogate mothers and the MSCs used as the nuclear donors. There were $100 \%$ similarities between the genotypes of the piglets and the donor cells (Table 3).

\section{Discussion}

Miniature pigs continue to elicit interest as an animal model in the fields of biomedical research [12], transplantation organs [13, $14]$ and disease models [15, 16]. However, lack of comprehensive studies on miniature pigs and their cloning has made cloning in them less efficient than in other animals, including domestic pigs.

In the present study, the in vitro development of embryos cloned with undifferentiated MSCs derived from bone marrow was higher than that of embryos cloned with differentiated MSCs and FFs. 


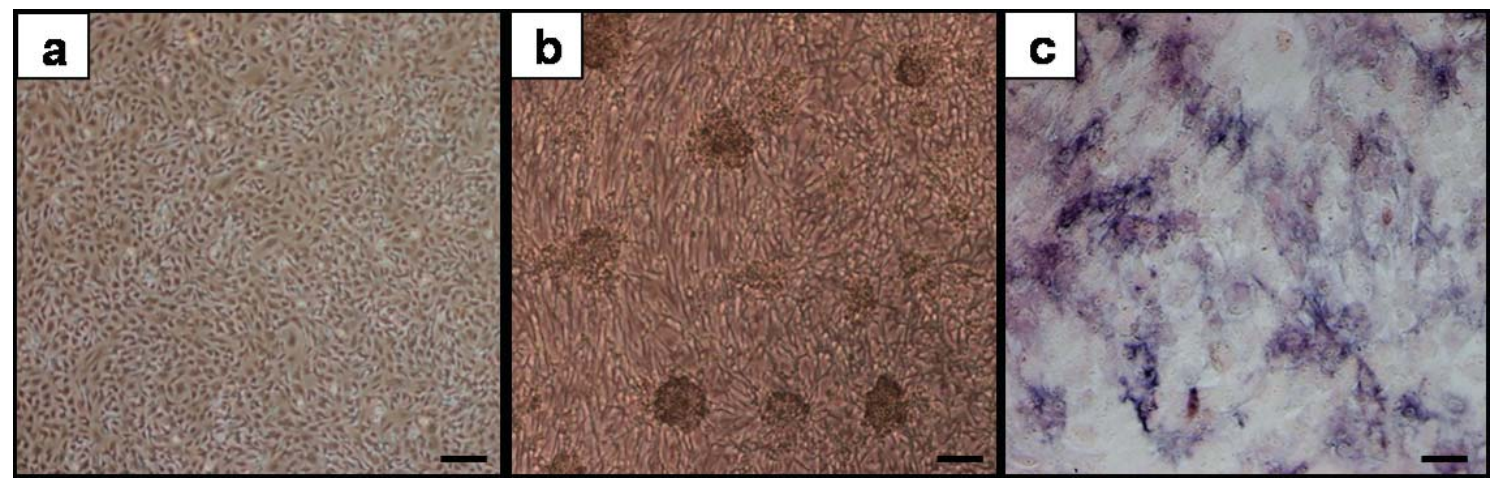

Fig. 1. MSCs derived from miniature pig bone marrow. Examination of morphology and AP activity in primary culture of MSCs revealed fibroblastic shape (a), homogeneous morphology (a) and colony formation (b). Staining with BCIP/NBT revealed alkaline phosphatase activity in MSCs that differentiated into osteocytes (c). Scale bars=100 $\mu \mathrm{m}$.
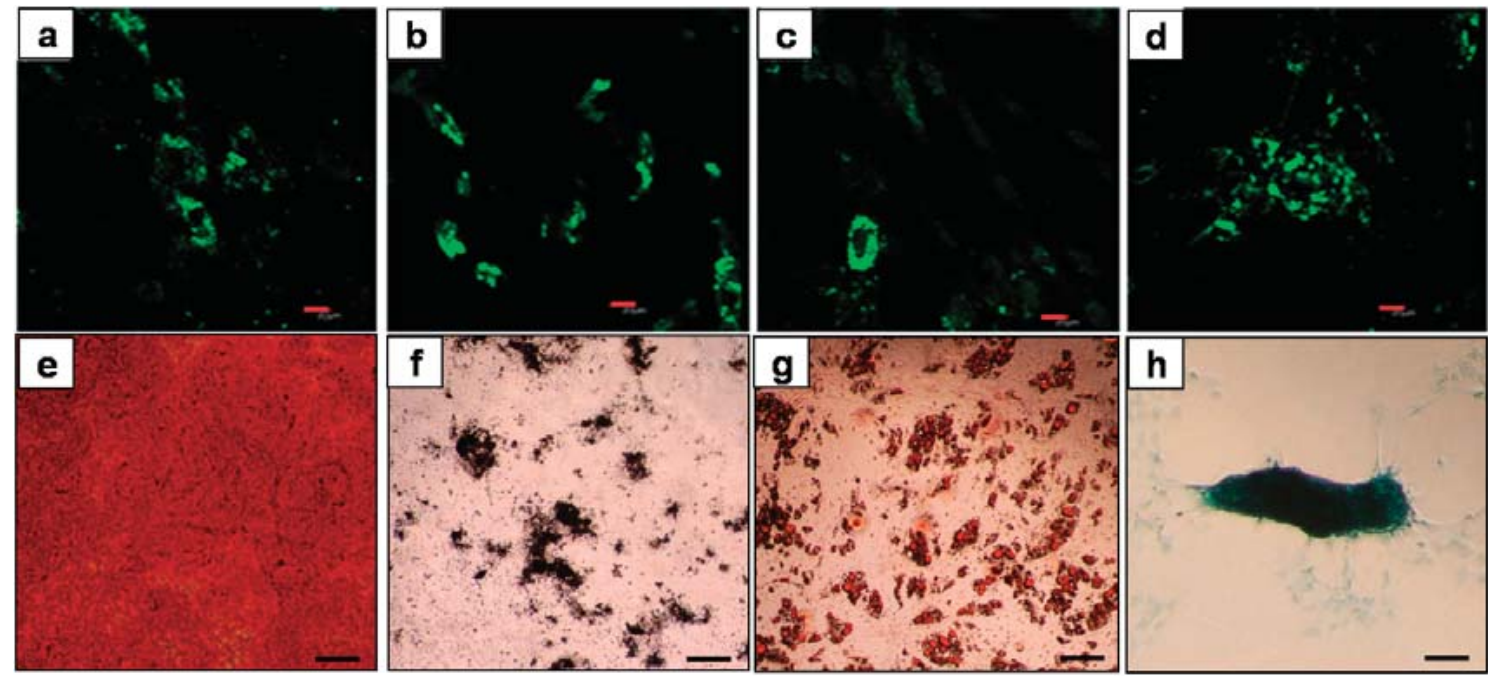

Fig. 2. Representative cell-surface antigen profiles (a-d) and images of differentiation potential (e-h) of MSCs. Green fluorescence indicates the positions of CD13 (a), CD29 (b), CD44 (c) and CD105 (d) as MSC specific markers. Cytochemical staining confirmed that MSCs differentiated into osteogenic, adipogenic and chondrogenic lineages. Osteogenic induction was assessed by Alizarin-red S solution (e) and von Kossa staining for identification of the mineralized matrix (f). Adipogenic induction was assessed by oil red $\mathrm{O}$ staining for accumulation of the lipid droplets (g) and Alcian blue 8 GX solution staining for synthesis of glycosaminoglycans in chondrocytes (h). Scale bars=20 $\mu \mathrm{m}(\mathrm{a}-\mathrm{d})$ and $100 \mu \mathrm{m}(\mathrm{e}-\mathrm{h})$.

Following transfer of embryos cloned with undifferentiated MSCs, we generated four viable miniature pig offspring. These findings indicate that MSCs are more efficient nuclear donors for cloning in terms of enhancing the pre-implantation development of cloned pig embryos. It has been hypothesized that the genome of undifferentiated cells or partially differentiated multipotent progenitor cells can be easily reprogrammed by recipient oocytes [4, 6, 8, 17-19]. MSCs have been isolated from bone marrow extracts in various animal species and established for in vivo or in vitro applications. Multipotent MSCs that had originally been identified by their ability to differentiate into mesenchymal lineages, such as osteogenic [20], chondrogenic [21, 22] and marrow stromal lineages [23], have been considered to be promising tools for tissue engineering and cellular therapies [21, 24, 25]. In addition, MSCs have expanded in vitro without any apparent modification in phenotype or loss of multipotent function.

In the present study, adherent MSCs retained fibroblast-like morphology during primary culture, and after removal of nonadherent cells, a number of colonies formed and expressed AP activity that steadily increased as time progressed. All these findings were similar to earlier observations [26, 27]. Furthermore, the cells were observed to be positive for MSC-specific markers, such as CD13, CD29, CD44 and CD105 (Fig. 2a-d). However, CD45 and CD133, hematopoietic lineage markers, were not expressed 
Table 1. Rates of development in vitro and total cell numbers of embryos cloned with various donor cells

\begin{tabular}{lcccc}
\hline Type of donor cell $^{1}$ & $\begin{array}{c}\text { Reconstructed } \\
\text { eggs }\end{array}$ & \multicolumn{2}{c}{ Development to (\% mean \pm SEM) } & \multirow{2}{*}{$\begin{array}{c}\text { Total No. of cells }^{2} \\
\text { (mean } \pm \text { SEM) }\end{array}$} \\
\cline { 3 - 4 } & 334 & $216(64.7 \pm 4.1)^{\mathrm{a}}$ & $48(14.5 \pm 4.3)^{\mathrm{a}}$ & $31.1 \pm 3.8^{\mathrm{a}}$ \\
\hline FFs & 329 & $280(85.1 \pm 3.8)^{\mathrm{c}}$ & $157(47.7 \pm 3.2)^{\mathrm{c}}$ & $47.8 \pm 4.6^{\mathrm{b}}$ \\
MSCs & 296 & $213(72.0 \pm 4.6)^{\mathrm{b}}$ & $102(34.5 \pm 3.3)^{\mathrm{b}}$ & $40.5 \pm 5.7^{\mathrm{b}}$ \\
Osteocyte-MSCs & 293 & $188(64.2 \pm 2.4)^{\mathrm{a}}$ & $91(31.1 \pm 4.1)^{\mathrm{b}}$ & $40.3 \pm 4.8^{\mathrm{b}}$ \\
Adipocyte-MSCs & 315 & $237(75.2 \pm 2.8)^{\mathrm{ab}}$ & $116(36.8 \pm 3.5)^{\mathrm{b}}$ & $42.2 \pm 6.2^{\mathrm{b}}$ \\
\hline Chondrocyte-MSCs & &
\end{tabular}

${ }^{1}$ FF: fetal fibroblasts. MSCs: mesenchymal stem cells. Osteocyte-MSCs: differentiation of MSCs into osteocytes. Adipocyte-MSCs: differentiation of MSCs into adipocytes. Chondrocyte-MSCs: differentiation of MSCs into chondrocytes.

${ }^{2}$ The mean total number of cells in cloned blastocysts recovered at day 7. ${ }^{\mathrm{a}, \mathrm{b}, \mathrm{c}}$ Percentages with different superscripts within a column are significantly different $(\mathrm{P}<0.05)$. Ten replicates were performed.

Table 2. Pregnancy and offspring following transfer of embryos cloned with MSCs into surrogates

\begin{tabular}{lcccc}
\hline Surrogate pig $^{1}$ & $\begin{array}{c}\text { No. NT embryos } \\
\text { transferred }^{2}\end{array}$ & $\begin{array}{c}\text { Diagnosis of } \\
\text { pregnancy }(+/-)^{3}\end{array}$ & $\begin{array}{c}\text { Maintaining } \\
\text { gestation }\end{array}$ & No. offspring \\
\hline A & 110 & - & - & - \\
B & 92 & + & Abortion & - \\
C & 108 & + & Full-term & 4 (viable) \\
D & 115 & + & Full-term & 1 (stillbirth) \\
E & 98 & + & Abortion & - \\
\hline Total & 523 & & &
\end{tabular}

${ }^{1}$ One-year-old female (crossbred of Landrace $\times$ Yorkshire). ${ }^{2}$ NT embryos derived from MSCs transferred into the uteri of estrus synchronized surrogate mother pigs. ${ }^{3}$ Diagnosed at around 28 days after transfer using a ultrasound equipped with 7.0-MHz convex transducer.

Table 3. Microsatellite analysis of the genomes of the cloned offspring, donor MSCs and surrogate mothers

\begin{tabular}{lccc}
\hline Markers & Donor MSCs & Offspring & Surrogate mothers \\
\hline S0090 & $243 / 247$ & $243 / 247$ & $247 / 249$ \\
S0155 & $160 / 162$ & $160 / 162$ & $152 / 156$ \\
S0228 & $237 / 237$ & $237 / 237$ & $221 / 225$ \\
S0355 & $258 / 264$ & $246 / 246$ \\
S0386 & $168 / 264$ & $166 / 166$ & $162 / 162$ \\
SW240 & $166 / 166$ & $91 / 101$ & $91 / 95$ \\
SW787 & $91 / 101$ & $146 / 158$ & $154 / 156$ \\
SW911 & $146 / 158$ & $155 / 159$ & $155 / 167$ \\
\hline
\end{tabular}

(data not shown). These observations show a consensus that MSCs do not express hematopoietic stem cell markers.

MSCs from 3 to 4 passages were induced to differentiate into osteogenic, adipogenic and chondrogenic lineages under specific culture conditions, and staining confirmed the multilineage differentiation of these three classical mesenchymal pathways (Fig. 2eh). According to previous reports, $>5$ passage porcine MSCs retain multipotential capacity (the three principle lineages), but $<15$ passage MSCs retain only adipogenic capacity [10] or capacity toward the osteogenic lineage [28]. In the present study, the MSCs at an early passage stage successfully differentiated into the three principle lineages. Based on the findings, the cells were confirmed to be multipotent [7, 26, 27] and were used as nuclear donors for NT.

According to numerous studies, the type of donor cell could be considered the prime cause affecting the developmental ability of cloned embryos, and the progressive decrease in cloning efficiency has been related to the differentiation status of the donor cell [29]. In general, due to rapid growth and the potential for multiple cell divisions, fetal fibroblasts have been commonly used as nuclear donors in pig embryo cloning. The blastocyst rates of pig embryos cloned with FFs are below the level of 20\% [30-32]. These data are substantially in accordance with our data showing that $14.5 \%$ of embryos cloned with FFs developed to blastocysts. MSCs have been successfully established, and these cells have been further employed as nuclear donors for porcine NT [6-8, 33]. Similarly, pig embryos cloned with undifferentiated MSCs and their derivatives along the osteogenic lineage gave rise to consistently high development rates that are comparable to those of adult fibroblasts 
[6]. In the present study, the highest rate of blastocyst formation of the embryos cloned with undifferentiated MSCs implied that differentiated cells as nuclear donors may decrease cloning efficiency. Furthermore, the higher total cell numbers in embryos cloned with undifferentiated MSCs and their derivatives suggested that embryos cloned with MSCs are of higher quality than embryos cloned with differentiated cells. These findings are similar to the observations of the above-mentioned studies. Our group has observed the expression profiles of genes involved in transcription, DNA methylation, histone deacetylation, apoptosis and embryonic growth at different developmental stages, and some genes in embryos cloned with MSCs closely resembled those of in vivo produced embryos [7].

The usefulness of miniature pigs as an animal model has been proven; but nevertheless, only a limited number of studies have reported on cloned miniature pigs derived from somatic donor cells [30, 31, 34-36]. Because of the comparison with domestic pigs, production of cloned miniature pigs using miniature pigs oocytes has limitations. The strain or origin of the recipient oocytes and surrogate mother could affect the developmental and pregnancy rates of the cloned animals. The difference in strain of the surrogate miniature pig affects the post-implantation development of miniature pig NT embryos [34]. On the other hand, viable cloned [30, 35] and transgenic [36] miniature pigs have been produced using domestic pig oocytes as recipient oocytes and surrogate mothers.

In the present study, transfer of domestic pig oocyte-miniature pig MSC complexes into 5 domestic pig surrogates yielded 2 pregnancies. Offspring (4 viable and 1 stillborn) were obtained by natural delivery after approximately 115 days of gestation. The body weights of the cloned offspring were similar to those of noncloned miniature offspring, ranging from 190 to $320 \mathrm{~g}$, and were comparable to the observations made in previous report [32]. To clarify the offspring's genetic identity, eight polymorphic microsatellites (SW240, SW787, SW911, S0090, S0155, S0228, S0355, S0386) were analyzed from the cloned piglets, surrogate mothers and MSCs used as the nuclear donors. There were $100 \%$ similarities between the genotypes of the piglets and the donor cells. These results strongly verified the donor cell line as the source of the genetic material used to produce the cloned piglet. Hence, for miniature pig cloning, domestic pigs might be suitable animals for supplying the recipient oocytes and surrogate mothers.

In conclusion, this study demonstrated that miniature pig embryos cloned with undifferentiated MSCs and their derivatives along the osteogenic, adipogenic and chondrogenic lineages give rise to consistently high development rates that are comparable to fibroblasts, with significantly higher cell numbers. In addition to enhanced in vitro development potential, embryos cloned with MSCs developed to full term in vivo. This evidence suggests that MSCs with a relatively undifferentiated genome could be more efficiently reprogrammed to reinitiate the expression of early embryonic genes and have greater ability as nuclear donors to support pre- and post-implantation development.

\section{Acknowledgments}

This study was supported by grants from the BioGreen 21 project, 20070301034041 and 200908FHT010204005, Rural Development Administration, Republic of Korea.

\section{References}

1. Perico N, Benigni A, Remuzzi G. Xenotransplantation in the $21^{\text {st }}$ century. Blood Purif 2002; 20: 45-54

2. Logan JS. Prospects for xenotransplantation. Curr Opin Immunol 2000; 12: 563-568.

3. Yanagimachi R. Cloning: experience from the mouse and other animals. Mol Cell Endocrinol 2002; 187: 241-248.

4. Rideout WM, Wakayama T, Wutz A, Eggan K, Jackson-Grusby L, Dausman J, Yanagimachi R, Jaenisch R. Generation of mice from wild-type and targeted ES cells by nuclear cloning. Nat Genet 2000; 24: 109-110.

5. Wakayama T, Rodriguez I, Perry AC, Yanagimachi R, Mombaerts P. Mice cloned from embryonic stem cells. Proc Natl Acad Sci USA 1999; 96: 14984-14989.

6. Colleoni S, Donofrio G, Lagutina I, Duchi R, Galli C, Lazzari G. Establishment, differentiation, electroporation, viral transduction, and nuclear transfer of bovine and porcine mesenchymal stem cells. Cloning Stem Cells 2005; 7: 154-166.

7. Kumar BM, Jin HF, Kim JG, Ock SA, Hong Y, Balasubramanian S, Choe SY, Rho GJ. Differential gene expression patterns in porcine nuclear transfer embryos reconstructed with fetal fibroblasts and mesenchymal stem cells. Dev Dyn 2007; 236: 435446.

8. Faast R, Harrison SJ, Beebe LF, McIlfatrick SM, Ashman RJ, Nottle MB. Use of adult mesenchymal stem cells isolated from bone marrow and blood for somatic cell nuclear transfer in pigs. Cloning Stem Cells 2006; 8: 166-173.

9. Yoshioka K, Suzuki C, Tanaka A, Anas IM, Iwamura S. Birth of piglets derived from porcine zygotes cultured in a chemically defined medium. Biol Reprod 2002; 66: 112 119

10. Vacanti V, Kong E, Suzuki G, Sato K, Canty JM, Lee T. Phenotypic changes of adult porcine mesenchymal stem cells induced by prolonged passaging in culture. $\mathrm{J} \mathrm{Cell}$ Physiol 2005; 205: 194-201.

11. Kim YS, Lee SL, Ock SA, Balasubramanian S, Choe SY, Rho GJ. Development of cloned pig embryos by nuclear transfer following different activation treatments. Mol Reprod Dev 2005; 70: 308-313.

12. Polejaeva IA, Chen SH, Vaught TD, Page RL, Mullins J, Ball S, Dai Y, Boone J, Walker S, Ayares DL, Colman A, Campbell KH. Cloned pigs produced by nuclear transfer from adult somatic cells. Nature 2000; 407: 86-90.

13. Van Dorp AG, Verhoeven MC, Koerten HK, Van Der Nat-Van Der Meij TH, Van Blitterswijk CA, Ponec M. Dermal regeneration in full-thickness wounds in Yucatan miniature pigs using a biodegradable copolymer. Wound Repair Regen 1998; 6: 556-568.

14. Xu Q, Yu D, Qiu Y, Zhang H, Ding Y. Function of a new internal bioartificial liver: an in vitro study. Ann Clin Lab Sci 2003; 33: 306-312.

15. Larsen MO, Rolin B. Use of the Gottingen minipig as a model of diabetes, with special focus on type 1 diabetes research. ILAR J 2004; 45: 303-313.

16. Millikan LE, Boylon JL, Hook RR, Manning PJ. Melanoma in Sinclair swine: a new animal model. J Invest Dermatol 1974; 62: 20-30.

17. Zhu H, Craig JA, Dyce PW, Sunnen N, Li J. Embryos derived from porcine skinderived stem cells exhibit enhanced preimplantation development. Biol Reprod 2004, 71: $1890-1897$.

18. Rideout WM, Eggan K, Jaenisch R. Nuclear cloning and epigenetic reprogramming of the genome. Science 2001; 293: 1093-1098.

19. Oback B, Wells DN. Donor cell differentiation, reprogramming, and cloning efficiency: elusive or illusive correlation? Mol Reprod Dev 2007; 74: 646-654.

20. Jaiswal N, Haynesworth SE, Caplan AI, Bruder SP. Osteogenic differentiation of purified, culture expanded human mesenchymal stem cells in vitro. J Cell Biochem 1997; 64: 295-312.

21. Johnstone B, Hering TM, Caplan AI, Goldberg VM, Yoo JU. In vitro chondrogenesis of bone marrow-derived mesenchymal progenitor cells. Exp Cell Res 1998; 238: $265-$ 272

22. Mackay AM, Beck SC, Murphy JM, Barry FP, Chichester CO, Pittenger MF. Chondrogenic differentiation of cultured human mesenchymal stem cells from marrow. Tissue Eng 1998; 4: 415-428

23. Cheng L, Qasba P, Vanguri $\mathbf{P}$, Thiede MA. Human mesenchymal stem cells support megakaryocyte and pro-platelet formation from CD34 (+) hematopoietic progenitor cells. J Cell Physiol 2000; 184: 58-69.

24. Le Blanc K, Ringden O. Immunobiology of human mesenchymal stem cells and future use in hematopoietic stem cell transplantation. Biol Blood Marrow Transplant 
2005; 11: 321-334.

25. Shukla D, Box GN, Edwards R, Tyson DR. Bone marrow stem cells for urologic tissue engineering. World J Urol 2008; 26: 341-349.

26. Pittenger MF, Mackay AM, Beck SC, Jaiswal RK, Douglas R, Mosca JD, Moorman MA, Simonetti DW, Craig S, Marshak DR. Multilineage potential of adult human mesenchymal stem cells. Science 1999; 284: 143-147.

27. Bosch P, Pratt SL, Stice SL. Isolation, characterization, gene modification, and nuclear reprogramming of porcine mesenchymal stem cells. Biol Reprod 2006; 74: 46-57.

28. Banfi A, Bianchi G, Notaro R, Luzzatto L, Cancedda R, Quarto R. Replicative aging and gene expression in long-term cultures of human bone marrow stromal cells. Tissue Eng 2002; 8: 901-910.

29. Sun FZ, Moor RM. Nuclear transplantation in mammalian eggs and embryos. Curr Top Dev Biol 1995; 30: 147-176.

30. Wakai T, Sugimura S, Yamanaka K, Kawahara M, Sasada H, Tanaka H, Ando A, Kobayashi E, Sato E. Production of viable cloned miniature pig embryos using oocytes derived from domestic pig ovaries. Cloning Stem Cells 2008; 10: 249-262.

31. Li Y, Liu J, Dai J, Xing F, Fang Z, Zhang T, Shi Z, Zhang D, Chen X. Production of cloned miniature pigs by enucleation using the spindle view system. Reprod Domest
Anim 2008; 15: 1-6.

32. Miyoshi K, Inoue S, Himaki T, Mikawa S, Yoshida M. Birth of cloned miniature pigs derived from somatic cell nuclear transferred embryos activated by ultrasound treatment. Mol Reprod Dev 2007; 74: 1568-1574.

33. Jin HF, Kumar BM, Kim JG, Song HJ, Jeong YJ, Cho SK, Balasubramanian S, Choe SY, Rho GJ. Enhanced development of porcine embryos cloned from bone marrow mesenchymal stem cells. Int J Dev Biol 2007; 51: 85-90.

34. Hoshino Y, Uchida M, Shimatsu Y, Miyake M, Nagao Y, Minami N, Yamada M, Imai H. Developmental competence of somatic cell nuclear transfer embryos reconstructed from oocytes matured in vitro with follicle shells in miniature pig. Cloning Stem Cells 2005; 7: 17-26.

35. Lai L, Kolber-Simonds D, Park KW, Cheong HT, Greenstein JL, Im GS, Samuel M, Bonk A, Rieke A, Day BN, Murphy CN, Carter DB, Hawley RJ, Prather RS. Production of alpha-1,3-galactosyltransferase knockout pigs by nuclear transfer cloning. Science 2002; 295: 1089-1092.

36. Kurome M, Ishikawa T, Tomii R, Ueno S, Shimada A, Yazawa H, Nagashima H. Production of transgenic and non-transgenic clones in miniature pigs by somatic cell nuclear transfer. J Reprod Dev 2008; 54: 156-163. 